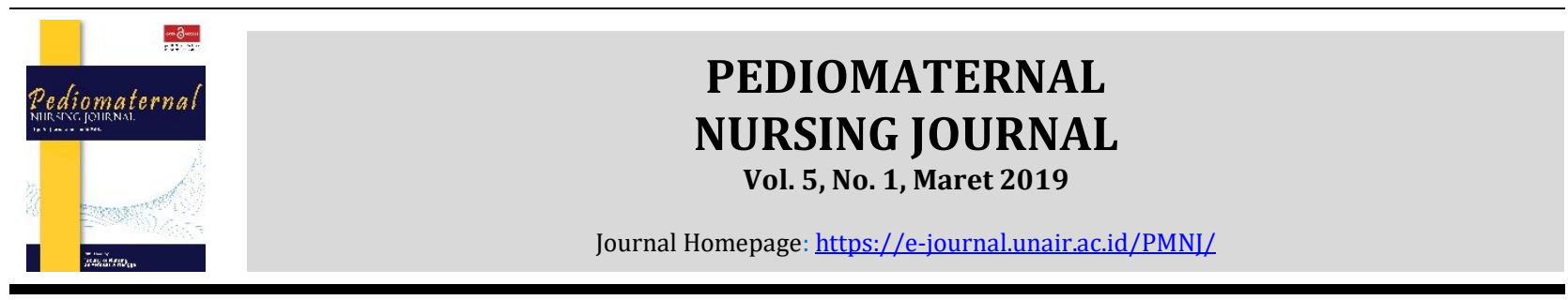

Original Research

\title{
Gambaran Resiliensi Anak Usia Sekolah Pasca Bencana Gunung Kelud
}

\author{
(Resilience Description of School-Age Children after the Mount Kelud Disaster)
}

\author{
Hasanudin Hasanudin, Yuni Sufyanti Arief, Iqlima Dwi Kurnia dan Tiyas Kusumaningrum \\ Fakultas Keperawatan, Universitas Airlangga, Surabaya, Jawa Timur, Indonesia
}

\section{ARTICLE HISTORY}

Received: March 18, 2019

Accepted: April 11, 2019

\section{KEYWORDS}

resilience; school; children; disaster

\section{CORRESPONDING AUTHOR}

Hasanudin Hasanudin hasanuding020@gmail.com Fakultas Keperawatan, Universitas Airlangga, Surabaya, Jawa Timur, Indonesia

\begin{abstract}
Introduction: Natural disasters can affect the psychological well-being and mental health of people. If children do not have good endurance, they will be affected by traumatic events that initially show reactive phenomena, so they can continue and lead to psychological disorders. The purpose of the study was to describe the resilience of school-age children after the Kelud mountain disaster.

Methods: This study uses a quantitative descriptive research design. Samples were collected using simple random sampling technique. The total sample is 56 respondents. The independent variable is resilience. The dependent variable is the kelud mountain disaster. Data was collected using a structured questionnaire. Data were analyzed using chi-square statistical test.

Results: The ability to rehabilitate school-aged children after the Kelud mountain disaster in Penataran 02 Elementary School showed moderate ability on impulse control aspects (69.6\%), causal analysis (67.5\%), self-efficacy (69.1\%), empathy ( $70.2 \%)$, and optimistic (72.6\%), while the ability that is classified as low is reaching out (59.4\%) and emotion regulation (58.0\%), with interpretation the resilience score is said to be high if the score is $76-100 \%$, Medium: $60=75 \%$, Low: $<60 \%$.

Conclusion: Resilience can be improved through changes in emotional regulation, impulse control, causal analysis, self-efficacy, optimism, empathy, and positive abilities. For further researchers, it is expected to focus on the dominant factors that affect children's resilience.
\end{abstract}

Hasanudin, H., Arief, Y. S., Kurnia, I. D., \& Kusumaningrum, T. (2019). Gambaran Resiliensi Anak Usia Sekolah Pasca Bencana Gunung Kelud. Pediomaternal Nurs. J., 5(1), 43-48.

Cite this as:

beradaptasi sangat diperlukan, jika resiliensi anak terhadap bencana turun, maka anak rentan terkena gangguan psikologis.

Peristiwa traumatis dan kehilangan adalah hal biasa dalam kehidupan manusia. Dalam penelitian WHO sebelumnya di 21 negara, Diperkirakan 3,6\% dari populasi dunia telah menderita Post Traumatic Stress Dissorder (PTSD). Berdasarkan hasil penelitian (3), menunjukkan bahwa dari 42 responden tinggal di Dukuh Kali Bladak lebih dari 16 tahun, 23 responden $(54,8 \%)$ memiliki gejala PTSD. 5 responden $(11,9 \%)$ memiliki banyak gejala PTSD. 18 responden $(42,9 \%)$ memiliki beberapa gejala PTSD. Jika PTSD tidak dilakukan suatu intervensi dapat menyebabkan depresi dan juga menurunkan resiliensi. 
Hasil penelitian (1), terkait tujuh faktor kemampuan resiliensi anak pasca bencana banjir di desa dayeuhkolot. Dari ketujuh faktor terdapat empat faktor yang memiliki hasil rendah yaitu, regulasi emosi, kemampuan empati, kemampuan reaching out dan self-efficacy. Hasilnya adalah dari kemampuan self-efficacy, sebanyak 3 orang $(9,68 \%)$ memiliki skor di atas rata-rata, sebanyak 12 orang $(38,71 \%)$ memiliki skor yang tergolong rata-rata dan sebanyak 16 orang $(51,61 \%)$ memiliki skor yang tergolong di bawah rata-rata. Studi pendahuluan yang dilakukan oleh peneliti pada siswa SD Negeri Penataran 02 Kecamatan Nglegok, Kabupaten Blitar, didapatkan data bahwa 4 (40\%) siswa mengatakan masih takut jika teringat pada peristiwa erupsi gunung kelud, dan $6(60 \%)$ siswa mengatakan bingung jika nanti gunung kelud meletus kembali. Dampak psikologis seperti PTSD merupakan masalah yang sering muncul terutama pada satu tahun pertama atau dua tahun setelah bencana atau bahkan bisa mucul sewaktuwaktu jika kejadian trauma itu terulang kembali (4).

Bencana alam dapat mempengaruhi kesejahteraan psikologis dan kesehatan mental orang, baik orang dewasa maupun anak-anak dan remaja (2). Oleh karena itu diperlukan pengembangan masyarakat yang memiliki kemampuan mengorganisasi, belajar dan beradaptasi dalam menghadapi bencana. Salah satu konsep psikologi yang menjelaskan tentang kemampuan tersebut adalah resiliensi. Resiliensi merupakan kemampuan menghadapi tantangan, resiliensi akan tampak ketika seseorang menghadapi pengalaman yang sulit dan tahu bagaimana menghadapi atau beradaptasi dengannya. Jika anak tidak memiliki ketahanan yang baik, anak akan terpengaruh terhadap peristiwa traumatis yang pada awalnya memperlihatkan fenomena reaktif, sehingga dapat berlanjut dan membawa kepada gangguan psikologis, apabila anak tersebut memiliki kepribadian yang rentan (5).

Hal tersebut akan menyisakan ingatan buruk pada mereka dan memberikan stressor yang besar. Salah satu dampak yang dapat terjadi karena pengalaman traumatis tersebut adalah terjadinya Post Traumatic Stress Dissorder (PTSD). Anak-anak dan remaja sangat rentan terhadap bunuh diri setelah bencana alam dikarenakan kurangnya pengetahuan dan pengalaman serta keterampilan koping mereka yang kurang berkembang, jika terus terjadi tanpa ada penangaan lebih lanjut, dapat menghambat pemulihan mereka setelah bencana dan membuat mereka lebih rentan terhadap tekanan psikologis. Hal itu dapat terjadi tergantung seberapa jauh kemampuan individu menyesuaikan diri terhadap perubahan yang terjadi dalam kehidupan yang lebih dikenal dengan resiliensi (6).

Resiliensi dapat ditingkatkan melalui perubahan cara pandang individu terhadap permasalahan yang dapat dilihat dalam tujuh kemampuan yaitu, Regulasi Emosi, Pegendalian Impuls, Analisis Kausal, selfefficacy, Optimis, Empati, dan meningkatkan kemampuan yang positif (7). Penelitian yang dilakukan oleh (1), kemampuan self-efficacy pada korban bencana alam cenderung rendah sehingga perlu diberikan intervensi yang dapat meningkatkan aspek-aspek kemampuan resiliensi tersebut, selfefficacy merupakan keyakinan pada kemampuan diri untuk menghadapi dan memecahkan masalah dengan efektif.

Bencana alam telah memberikan dampak yang signifikan secara fisik psikologis maupun sosial. Mengingat besarnya dampak yang ditimbulkan akibat bencana alam maka diperlukan suatu upaya yang menyeluruh dalam penyelenggaraan penanggulangan bencana baik ketika sedang terjadi maupun setelah bencana berakhir yang beresiko terhadap persoalan fisik, psikis maupun social (1). Pengembangan model peningkatan resiliensi anak usia sekolah di daerah rawan bencana dapat dilakukan oleh perawat dengan melakukan pendidikan dan promosi kesehatan sebagai bagian dari disaster nursing competencie (5). Perawat dapat meningkatkan program promosi kesehatan dengan menerapkan strategi Psychological Care dan mengidentifikasi tumbuh kembang anak sekolah didaerah rawan bencana sebagai upaya preventif sebelum terjadi bencana dan sebagai upaya rehabilitatif pasca bencana. Upaya promotif terhadap resiliensi anak usia sekolah perlu dukungan dari berbagai faktor yaitu dengan meningkatkan keterlibatan orang tua dan lingkungan eksternal karena merupakan faktor yang berpengaruh signifikan dalam peningkatan resiliensi anak sekolah sehingga mampu menurunkan gejala PTSD pada anak.

Sebelum dilakukan suatu intervensi yang lebih lanjut peneliti ingin me

lakukan penelitian terkait gambaran resiliensi anak usia sekolah pasca bencana gunung kelud di SD Negeri Penataran 02 Kecamatan Nglegok Kabupaten Blitar.

\section{METODE}

\subsection{Desain}

Penelitian yang dilakukan merupakan jenis penelitian descriptive.

\subsection{Populasi, sampel, dan sampling}

Populasi target dalam penelitian ini yaitu semua siswa SD Negeri Penataran 02, Kabupaten Blitar sebanyak 162 siswa, sedangkan populasi terjangkau pada penelitian ini adalah siswa kelas IV dan V SD Negeri Penataran 02 tahun ajaran 2017/2018 yang berjumlah 65 siswa. Sampel dalam penelitian ini sebanyak 56 anak diambil dengan teknik simple random sampling. Kriteria inklusi dalam penelitian ini adalah anak usia 9-12 tahun, anak yang tinggal di wilayah ring 1 gunung kelud sejak tahun 2014 . Kriteria Eksklusi dalam penelitian ini adalah Anak yang tidak masuk saat dilakukan penelitian, Tidak mengikuti sesi penelitian dengan lengkap, Responden yang mengundurkan diri. 


\subsection{Variabel}

Variabel dalam penelitian ini adalah gambaran resiliensi anak usia sekolah pasca bencana gunung kelud.

\subsection{Instrumen}

Instrumen Penelitian dalam penelitian ini adalah kuesioner resiliensi. Pernyataan dalam kuesioner resiliensi ini terdiri dari dua jenis pernyataan yaitu pernyataan favorabel (positif) dan unvaforable (negatif). Dalam penelitian ini menggunakan 5 (lima) alternatif jawaban yaitu Sangat Sesuai (SS), Sesuai (S) Kurang Sesuai (KS), Tidak Sesuai (TS), dan Sangat Tidak Sesuai (STS).

Kuesioner resiliensi dari (1) ini telah dimodifikasi oleh peneliti dan terdiri dari 28 pertanyaanmeliputi aspek regulasi emosi (no 1,2,3,4), kontrol terhadap implus (no 5,6,7,8) , kemampuan menganalisis masalah (no 9,10,11,12), efikasi diri (no 13,14,15,16), optimis (no17,18,19,20), empati (no 21,22,23,24), dan pencapaian (no 25,16,27,28). Penilaian pernyataan favorabel (positif) dengan kode 1=sangat tidak sesuai, 2=tidak sesuai, 3= kurang sesuai, 4=sesuai, 5=sangat sesuai, sedangkan Penilaian pernyataan unfavorabel (negatif) dengan kode 1 =sangat sesuai, $2=$ sesuai, $3=$ kurang sesuai, $4=$ tidak sesuai, 5=sangat tidak sesuai, lalu peneliti mengkategorikan resiliensi menjadi 3 kategori yaitu kategori baik (76\%-100\%), cukup (56\%-75\%), dan kurang $(\leq 55 \%)$.

\subsection{Prosedur}

Peneliti meminta ijin kepada pihak Badan Kesatuan Bangsa dan Politik Kabupaten Blitar dengan menyerahkan surat permohonan pengantar penelitian dari Fakultas Keperawatan Universitas Airlangga untuk melakukan penelitian di SD Negeri Penataran 02 Kecamatan Nglegok selama satu bulan, setelah mendapatkan izin kemudian peneliti menyerahkan surat tembusan kepada Dinas Pendidikan Kabupaten Blitar dan juga kepada SD Negeri Penataran 02 untuk melakukan penelitian.

Peneliti melakukan koordinasi dengan guru SD Negeri Penataran 02 mengenai jadwal penelitian dan juga teknis penelitian, kemudian Peneliti menyeleksi siswa yang memenuhi kriteria inklusi agar peneliti bisa mendapatkan sampel sebanyak 56 responden yang terbagi menjadi 2 kelas, yaitu kelas IV dan kelas $\mathrm{V}$, dengan menggunakan teknik simple random sampling.

Peneliti meminta persetujuan sebagai responden dengan memberikan informed consent (surat persetujuan menjadi subjek penelitian) dan lampiran data demografi kepada semua siswa kelas IV dan V. Lembar informed consent ditanda tangani orang tua sebagai wali yang sebelumnya sudah dikoordinasikan dengan guru wali kelas. Lembar informed consent dan data demografi dibawa pulang dan dikumpulkan kembali pada guru wali kelas, peneliti mendatangi sekolah untuk mengambil lembar informed consent yang sudah diisi oleh orangtua responden yang dikumpulkan kepada guru wali kelas. Peneliti mengecek kelengkapan jawaban informed consent dan lampiran data demografi, dan menanyakan kembali pada responden apabila ada yang belum diisi dengan lengkap. Kemudian dilakukan pengumpulan data. Pengisian kuesioner dipandu oleh peneliti dengan cara memberikan penjelasan singkat cara pengisian kuesioner.

\subsection{Analisis}

Penelitian ini dilakukan analisis dengan IBM SPSS Statistic 25 dengan uji Chi-Square.

\subsection{Ethical Clearance}

Penelitian ini telah dinyatakan lolos kaji etik dan mendapatkan sertifikat Ethical Approval dengan No. 1214 -KEPK yang dikeluarkan oleh Komite Etik Penelitian Kesehatan Fakultas Keperawatan Universitas Airlangga pada tanggal 12 Desember 2018.

\section{Hasil}

Karakteristik responden menunjukan dari segi kelas , responden terbagi menjadi 2 kelas yaitu kelas IV dan kelas $\mathrm{V}$ dengan prosentase terbanyak kelas IV yaitu 30 orang $(53,6 \%)$. Dilihat dari segi usia, semua responden berada pada usia anak sekolah yaitu usia 9-12 tahun dengan persentase terbanyak pada usia 10 tahun yaitu sebanyak 25 orang $(44,6 \%)$. Dilihat dari jenis kelamin, responden berjenis laki-laki dan kelamin perempuan adalah sama yaitu masingmasing 28 anak $(50,0 \%)$. Dari segi pendidikan ayah sebanyak 21 orang $(37,5 \%)$ ayah responden memiliki tingkat pendidikan SMA. Dari segi pendidikan ibu sebanyak 22 orang (39,3 \%) ibu responden memiliki tingkat pendidikan SMA. Dilihat dari segi pekerjaan, sebagian besar orang tua responden bekerja sebagai wiraswasta yaitu 20 orang $(35,7 \%)$. Dilihat dari segi penghasilan, sebagian besar orang tua responden berpenghasilan $\mathrm{Rp}$ 500.000-1.000.000 setiap bulannya yaitu 21 orang (37,5\%). Dari segi dampak letusan gunung kelud tahun 2014 sebanyak 36 orang (64,5\%) terkena dampak parah dari letusan gunung kelud. Dilihat dari keadaan penduduk yang mengungsi, sebanyak 49 $(87,5 \%)$ memilih untuk mengungsi pada bencana gunung kelud tahun 2014 [Tabel 1].

Kemampuan resliensi anak usia sekolah pasca bencana gunung kelud di SD Negeri Penataran 02 menunjukkan kemampuan yang sedang pada aspek pengendalian impuls $(69,6 \%), \quad$ analisis kausal(67,5\%), self-efficacy $(69,1 \%)$, empati $(70,2 \%)$, dan optimis $(72,6 \%)$, sedangkan kemampuan yang tergolong rendah adalah reaching out $(59,4 \%)$ dan regulasi emosi (58,0\%), dengan Intepretasi skor resiliensi dikatakan tinggi jika skor $76-100 \%$, Sedang :60=75\%, Rendah: $<60 \%$ [Tabel 2].

\section{PEMBAHASAN}

Kemampuan resiliensi anak usia sekolah pasca bencana gunung kelud yang tergolong tinggi adalah 


\section{H. HASANUDIN ET AL.}

optimis, kemampuan resiliensi yang tergolong sedang adalah implus kontrol, analisis kausal, selfefficacy, kemampuan resiliensi yang tergolong rendah adalah regulasi emosi dan reaching out.

Resiliensi dapat ditingkatkan melalui perubahan cara pandang individu terhadap permasalahan yang dapat dilihat dalam tujuh kemampuan yaitu, regulasi emosi, pegendalian impuls, analisis kausal, self- tahun) dapat merespon dengan cemas, regresi, atau masalah makan yang meningkat. Anak-anak yang sedikit lebih tua (2-7 tahun) dapat merespon dengan insomnia, mimpi buruk, peningkatan kekhawatiran, sensitivitas suara, atau lekas marah. Anak-anak sekolah dasar (usia 7-11 tahun) mungkin menunjukkan lebih banyak kemarahan, agresi, dan bertingkah mirip dengan remaja. Anak yang tidak

Tabel 1. Karakteristik responden gambaran resiliensi anak usia sekolah pasca bencana gunung kelud, Desember 2018

\begin{tabular}{|c|c|c|c|}
\hline & Kategori & $\mathbf{n}$ & $(\%)$ \\
\hline \multirow[t]{2}{*}{ Kelas } & Kelas IV & 30 & 53.6 \\
\hline & Kelas V & 26 & 46.4 \\
\hline \multirow[t]{4}{*}{ Usia } & 9 Tahun & 10 & 17.9 \\
\hline & 10 Tahun & 25 & 44.6 \\
\hline & 11 Tahun & 13 & 23.2 \\
\hline & 12 Tahun & 8 & 14.3 \\
\hline \multirow[t]{2}{*}{ Jenis Kelamin } & Laki-Laki & 28 & 50 \\
\hline & Perempuan & 28 & 50 \\
\hline \multirow[t]{3}{*}{ Pendidikan Ayah } & SD & 17 & 30.4 \\
\hline & SMP & 18 & 32.1 \\
\hline & SMA & 21 & 37.5 \\
\hline \multirow[t]{4}{*}{ Pendidikan Ibu } & SD & 16 & 28.6 \\
\hline & SMP & 15 & 26.8 \\
\hline & SMA & 22 & 39.3 \\
\hline & S1 & 3 & 5.4 \\
\hline \multirow[t]{4}{*}{ Pekerjaan Orang Tua } & Wiraswasta & 20 & 35.7 \\
\hline & Petani & 16 & 28.6 \\
\hline & Pedagang & 11 & 19.6 \\
\hline & Lainnya & 9 & 16.1 \\
\hline \multirow[t]{5}{*}{ Penghasilan Orang Tua } & $>500.000$ & 15 & 26.8 \\
\hline & $500.000-1.000 .000$ & 21 & 37.5 \\
\hline & $1.500 .000-2.000 .000$ & 17 & 30.4 \\
\hline & $2.000 .000-2.500 .000$ & 2 & 3.6 \\
\hline & $>2.500 .000$ & 1 & 1.8 \\
\hline \multirow[t]{2}{*}{ Dampak Letusan Kelud } & Ya & 36 & 64.3 \\
\hline & Tidak & 20 & 35.7 \\
\hline \multirow[t]{2}{*}{ Mengungsi } & Ya & 49 & 87.5 \\
\hline & Tidak & 7 & 12.5 \\
\hline
\end{tabular}

Tabel 2. Hasil Skor 7 Faktor resiliensi di SD Negeri Penataran 02, Desember 2018

\begin{tabular}{llc}
\hline No & Variabel & Skor (\%) \\
\hline 1 & Regulasi Emosi & 58 \\
2 & Pengendalian Impuls & 69,6 \\
3 & Analisis Kausal & 67,5 \\
4 & Self-Efficacy & 69,1 \\
5 & Optimis & 72,7 \\
6 & Empati & 70,2 \\
7 & Reaching Out & 61,4 \\
\hline
\end{tabular}

efficacy, optimis, empati, dan meningkatkan kemampuan yang positif (7). Data yang diperoleh melalui kuesioner resiliensi yang telah di isi oleh responden menunjukkan hasil rendah yaitu pada faktor regulasi emosi, dan reaching out. Hal itu sesuai dengan hasil penelitian dari (8), pada anak-anak, tahap perkembangan dan fungsi kognitif juga mempengaruhi respon mereka.

Secara luas, tanggapan pasca trauma dapat dikategorikan ke dalam 3 kategori: afektif, perilaku, dan kognitif. Anak-anak yang sangat muda (0-2 mampu meningkatkan kemampuan yang positif (reaching out), dapat disebabkan rentang usia yang masih labil, seringkali mengalami kesulitan untuk dapat membayangkan dirinya di masa depan, kemana akan menuju, atau bahkan mungkin berpikir apakah akan pergi ke suatu tujuan.

Hal ini disebabkan adanya banyak perubahan dan ketidakstabilan, terkadang melakukan sesuatu tanpa tahu apa yang menjadi tujuan, menghindari kegagalan dan situasi yang memalukan, membuat kecenderungan individu untuk berlebihan-lebihan 
(overestimate) dalam memandang kemungkinan halhal buruk yang dapat terjadi di masa mendatang. Ketakutan atau kekhawatiran akan kegagalan menjadikan anak tidak memiliki keberanian dan membatasi diri untuk menetapkan suatu target dan usaha untuk mencapai suatu tujuan sehingga aspek reaching out ini rendah (9).

Terdapat satu faktor dari tujuh kemampuan meningkatkan resiliensi yang memiliki nilai baik yaitu optimis. Walaupun mereka terkena dampak dari bencana letusan gunung kelud, namun mereka cukup optimis dalam memandang masa depan mereka dan mereka juga percaya bahwa mereka dapat mampu menghadapi kesulitan yang mereka alami saat terjadi letusan gunug kelud tahun 2014 Hal tu dipengaruhi oleh pendidikan orang tua mereka. Orang tua yang memiliki pendidikan SMA, tentunya memiliki taraf/standar pemikiran tentang kehidupan yang lebih baik, hal ini akan berkait pula dengan pola asuh dan orientasi masa depan bagi anak-anaknya dalam memberikan gambaran tantang masa depan. orang tua yang berpendidikan SMA, orientasi yang akan diberikan kepada anak-anaknya juga berpendidikan SMA atau dimungkinkan lebih tinggi dari orang tuanya, hasil penelitiannya menyatakan bahwa terdapat pengaruh positif dan signifikan antara tingkat pendidikan orang tua terhadap pola asuh anak sebesar 19,1\%. Pengaruh positif itu dapat dilihat jika tingkat pendidikan orang tua semakin baik maka pola asuh semakin baik sehingga rasa optimis anak tentang masa depan akan terbentuk (10).

Bencana alam telah memberikan dampak yang signifikan secara fisik psikologis maupun sosial. Mengingat besarnya dampak yang ditimbulkan akibat bencana alam maka diperlukan suatu upaya yang menyeluruh dalam penyelenggaraan penanggulangan bencana baik ketika sedang terjadi maupun setelah bencana berakhir yang beresiko terhadap persoalan fisik, psikis maupun sosial. Jika tidak dilakukan suatu intervesi maka dapat menimbulkan gangguan psikologis pada anak dan tumbuh kembang mereka (1).

Hasil positif yang didapatkan jika orang memiliki resiliensi yang baik adalah pengentasan efek negatif dari stress, peningkatan dalam beradaptasi, pengembangan keterampilan koping yang efektif sehingga self-efficacy dari anak bisa meningkat (11). Menambahkan karakteristik manusia yang memiliki resiliensi tinggi adalah: cenderung easygoing dan mudah bersosialisasi, memiliki keterampilan berpikir yang baik (secara tradisional disebut inteligensi, yang juga meliputi keterampilan sosial dan kemampuan menilai sesuatu), memiliki orang di sekitar yang mendukung, memiliki satu atau lebih bakat atau kelebihan, yakin pada diri sendiri dan percaya pada kemampuannya dalam mengambil keputusan serta memiliki spiritualitas atau religiusitas (12).

\section{KESIMPULAN}

Berdasarkan hasil penelitian yang telah dilakukan di SD Negeri Penataran 02 Kecamatan Nglegok Kabupaten Blitar pada tanggal 3 - 15 Desember 2018, maka dapat disimpulkan bahwa: Kemampuan resliensi anak usia sekolah pasca bencana gunung kelud di SD Negeri Penataran 02 secara umum menunjukkan kemampuan yang sedang pada aspek pengendalian impuls, analisis kausal, self-efficacy, empati, dan optimis, sedangkan kemampuan yang tergolong rendah adalah reaching out dan regulasi emosi.

Bagi peneliti selanjutnya diharapkan dapat melakukan riset mengenai faktor yang paling dominan dalam mempengaruhi resiliensi anak, sehingga intervensi yang dilakukan dapat sesuai sasaran, jika intervensi yang dilakukan dapat sesuai sasaran maka lebih efektif dan efisien untuk meningkatkan resiliensi anak pasca bencana alam, karena kita ketahui bahwa di Indonesia ini banyak daerah yang rawan terjadi bencana, selain itu bagi peneliti selanjutnya dapat melakukan riset mengenai pengaruh self-efficacy terhadap kesiapsiagaan anak dalam menghadapi bencana alam.

\section{UCAPAN TERIMA KASIH}

Kami mengucapkan terima kasih kepada Kepala Sekolah SD Negeri Penataran 02 yang telah memberikan izin dan penerimaan kami untuk mengambil data sebagai bahan penelitian dan semua siswa SD Negeri Penataran 02 yang telah bersedia menjadi responden.

\section{DAFTAR PUSTAKA}

1. Taufiq R, Susanty E, S DT, Nurlina E. Gambaran Resiliensi Anak Pasca Bencana Banjir Di Desa Dayeuhkolot, Kabupaten Bandung, Jawa Barat. Wacana J Psikol. 2014;6(11):73-87.

2. Andrades M, García FE, Calonge I, MartínezArias R. Posttraumatic Growth in Children and Adolescents Exposed to the 2010 Earthquake in Chile and Its Relationship with Rumination and Posttraumatic Stress Symptoms. J Happiness Stud. 2018;19(5):1505-17.

3. Anam AK, Martiningsih W, Ilus I. PostTraumatic Stress Dissorder Of Kelud Mountain's Survivor Based On Impact of Event Scale-Revised (IES-R) In Kali Bladak Nglegok District Blitar Regency. J Ners dan Kebidanan (Journal Ners Midwifery). 2016;3(1):046-52.

4. Neria Y, Nandi A, Galea S. Post-traumatic stress disorder following disasters: A systematic review. Psychol Med. 2008;38(4):467-80. 


\section{H. HASANUDIN ET AL.}

5. Nuari NA. Model Of Resilience Improvement On School Age Children After The Kelud Mountain Eruption Based On Disaster Nursing Competency. 2014;1-11.

6. Tang W, Zhao J, Lu Y, Zha Y, Liu H, Sun Y, et al. Suicidality, posttraumatic stress, and depressive reactions after earthquake and maltreatment: A cross-sectional survey of a random sample of 6132 chinese children and adolescents. J Affect Disord. 2018;232:363-9.

7. Reivich $\mathrm{K}$, Shatte A. The Resilience Factor 7 Keys to finding Your Inner Strength and Overcoming Life's Hurdles. Three Rivers Press. 2002;1-24.

8. Latif F, Yeatermeyer J, Horne ZD, Beriwal S. Psychological Impact of Nuclear Disasters in Children and Adolescents. Child Adolesc
Psychiatr Clin N Am. 2015;24(4):811-22.

9. Erniati S, Yuliasesti E, Sari D. Peran Resiliensi dan Dukungan Sosial Keluarga terhadap Kebahagiaan Remaja. Pros Konf Nas Ke-7. 2018;78-85.

10. Kharmina N. Hubungan Antara Tingkat Pendidikan Orang Tua Dengan Orientasi Pola Asuh Anak Usia Dini. 2011;

11. Keye MD, Pidgeon AM. Investigation of the Relationship between Resilience, Mindfulness, and Academic Self-Efficacy. Open J Soc Sci. 2013;01(06):1-4.

12. Murphey, D., Barry, M., \& Vaughn B. Positive mental health: Resilience. Child Trends. Posit Ment Heal Resil. 2013;1-6. 